\title{
SOME PHYTOSEIID MITES (ACARI) OF PAPUA NEW GUINEA, WITH DESCRIPTIONS OF SIX NEW SPECIES
}

\author{
J.A. McMurtry and G.J. de Moraes ${ }^{1}$ \\ Division of Biological Control, Department of Entomology, University of Calıfornia, Riverside, Calıfornia 92521
}

\begin{abstract}
Fourteen species of Phytoseiidae, 6 of which are new, were collected in the Wau and Bulolo areas of Papua New Guinea. Descriptions and diagnoses are given for Typhlodromus gressitti n. sp., Amblyseius multisetosus n. sp., A. grandiductus n. sp., A. papuaensis n. sp., A. asperocervix n. sp., and $\boldsymbol{A}$. paucisetosus n. sp. Supplementary descriptions and illustrations are given for $A$. newsami (Evans) and Iphiseius dinguensis Wu.
\end{abstract}

\section{INTRODUCTION}

The phytoseiid fauna of Papua New Guinea has not been studied extensively. The present study is preceded only by that of Schicha and Gutierrez (in press) which recorded 3 new and 9 known species. In 1979 the senior author, during a one month period at the Wau Ecology Institute, Morobe Province, collected Phytoseiidae in the Wau-Bulolo area on various native and introduced plants. Fourteen species, 6 of which are new, are reported in this paper. Only 2 of these 14 were listed by Schicha and Gutierrez. A redescription of Amblyseius newsami (Evans) is included because of its similarity to one of the new species.

Most of the collections were made on the grounds of the Wau Ecology Institute (W.E.I.) from May 20 to June 12, 1979 at elevations of $1100-1400 \mathrm{~m}$. The mean annual rainfall in this area is $1887 \mathrm{~mm}$ (Gressitt and Nadkarni, 1978).

All measurements are in microns. The setal nomenclature follows that of Chant and Hansell (1971) and Rowell et al. (1978). The generic placement of species generally follows the concepts of Chant (1965).

The following abbreviations are used for museums or collections: USNM - U.S. National Museum of Natural History; UCR - Division of Biological Control, University of California, Riverside.

\section{Genus Typhlodromus Scheuten}

Typhlodromus Scheuten, 1857:111.

'Permanent address: CPATSA/EMBRAPA, 56300 Petrolina PE, Brazil.
Typhlodromus gressitti McMurtry \& Moraes, n.sp.

DIAGNOSIS: Typhlodromus miyari Ehara differs from $T$. gressittii by the much shorter setae Z5 (26). Typhlodromus brisbanensis Schicha and Typhlodromus crassus Van der Merwe have the posterior margin of the sternal shield lobate instead of straight and longer dorsal shield setae. $T$. brisbanensis further differs by having longer StIV (29) and a more elongate ventrianal shield. Typhlodromus gutierrezi Blommers has most of the dorsal shield setae longer (ca. 50\%) and a more elongate ventrianal shield. Typhlodromus gracilentus Tseng is also a closely related species, but it has longer dorsal shield setae (ca. 20\%), except for Z5, which is shorter (ca. 20\%).

FEMALE: (Figs. 1-4) (5 specimens measured). Dorsum: Dorsal shield reticulated, 298 (288-317) long, $182(178-190)$ wide at widest level of proscutum. Setae j1 12, j3 14 (13-14), j4 11 (10-12), j5 12, j6 15 (13-17), J2 19 (18-19), J5 6 (6-7), z2 13 (12-13), z3 14 (13-16), z4 15 (14-16), z5 12 (12-13), Z4 25 (24-26), Z5 48 (46-50), s4 18 (17-19), s6 21 (20-23), S2 21 (20-23), S4 20 (19-23), S5 15 (13-18), r3 15 (13-17), R1 14 (13-14). All setae smooth, except for Z5 which is barbed and knobbed. Peritreme: Extending beyond level of $\mathrm{j} 1$, with anterior end curved slightly backwards. Venter: Sternal shield with 3 pairs of setae and with posterior margin straight. Distances between sternal setae ST1ST3 52 (52-53), ST2-ST2 52 (52-53), and genital setae G-G 55 (53-56). Ventrianal shield subquadrate, 86 (78-90) long, 84 (83-86) wide at level of ZV2. Chelicera: Movable digit 23 long, with 3 teeth; fixed digit 22 long, with 4 teeth. Spermatheca: Cervix cup-shaped, 12 long. Atrium globate. Legs: Macrosetae knobbed, of the following lengths: SgeIV 8 (7-8), StiIV 14 


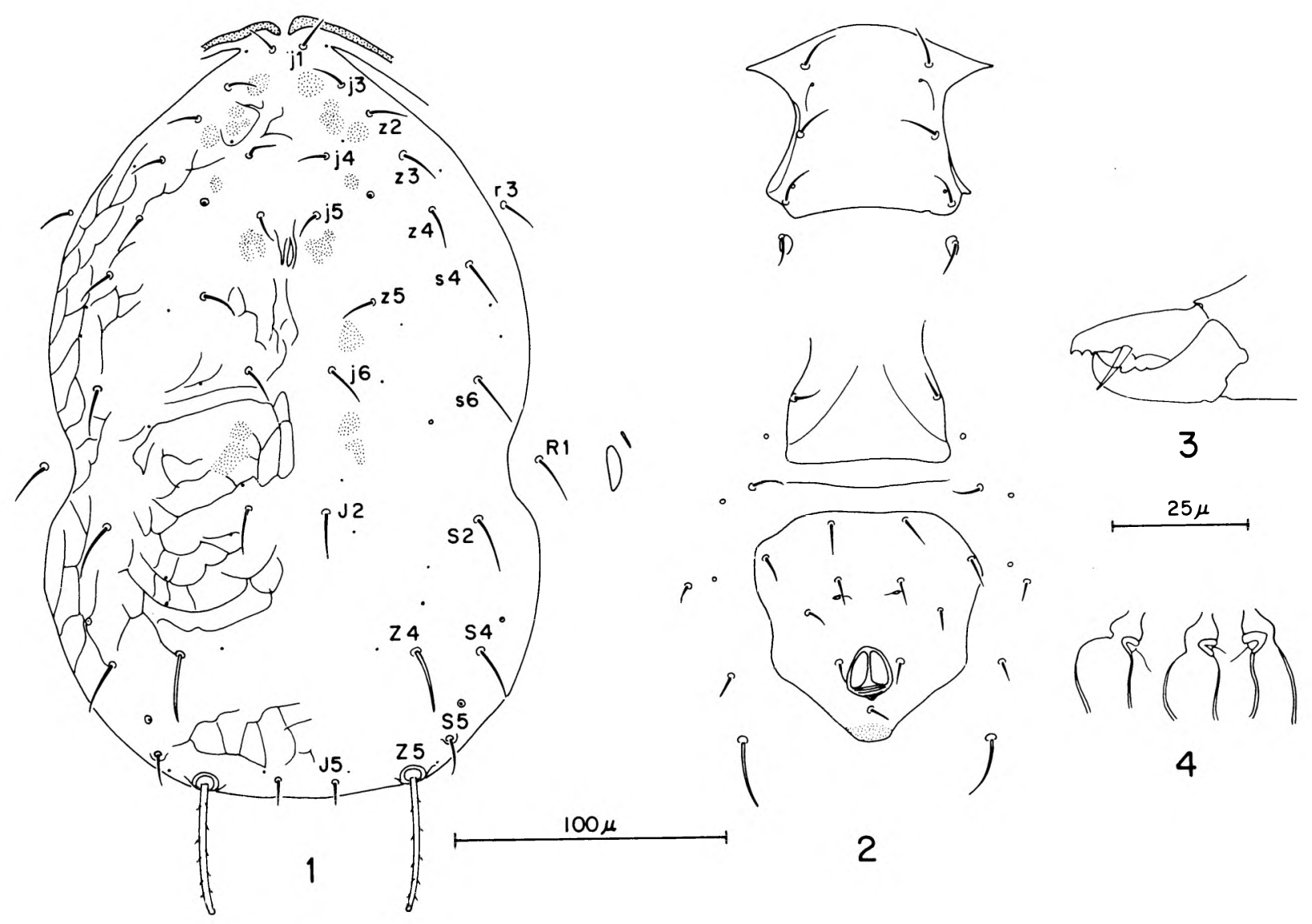

Figs. 1-4. Typhlodromus gressitti n. sp. Female: 1. dorsal shield 2. ventral surface 3. chelicera 4. spermatheca

(13-14), StIV 18 (18-19). Chaetotaxy of GeII $2, \frac{2-2}{0}$, 1; GeIII $1, \frac{2-2}{0}, 1$.

MALE: Unknown.

LOCALITY AND TYPE MATERIAL: Holotype female (in USNM) and 4 female paratypes (2 in USNM, 2 in UCR) from Cryptocarya sp., Wau, Papua New Guinea, 26-V-79. Two female paratypes (UCR), from Araucaria sp., Wau, Papua New Guinea, 4-VI-79 (J.A. McMurtry).

Genus Phytoseius Ribaga

Phytoseius Ribaga, 1902:177.

Phytoseius hongkongensis Swirski and Shechter

Phytoseius (Phytoseius) hongkongensis Swirski and Shechter, 1961:99; Denmark, 1966:44.

Phytoseius (Pennaseius) hongkongensis, Ehara and Lee, 1971:70.

Phytoseius hongkongensis, Schicha, 1984:126.

SPECIMENS EXAMINED: 4 FF (females), ex.
Tephrosia sp., Edie Creek Road, near W.E.I., elevation ca. $1700 \mathrm{~m}$., associated with Paraphytoseius cracentis (Corpuz and Rimando).

PREVIOUS RECORDS: Hong Kong (Ehara \& Lee 1971, Swirski \& Shechter 1961); Japan (Ehara 1972); Thailand (Ehara \& Bhandhufalck 1977); Taiwan (Tseng 1976); Madagascar (Blommers 1976); Australia (Schicha 1984).

REMARKS: The 4 Papua New Guinea specimens correspond closely in setal lengths and other details to the original description (Swirski and Shechter 1961) and that of Ehara and Lee (1971). Schicha and Gutierrez (in press) also report this species from Papua New Guinea. Schicha (1984) pointed out that some variations in setal lengths occur between populations of $P$. hongkongensis from different geographic areas.

Genus Paraphytoseius Swirski and Shechter

Paraphytoseius Swirski and Shechter, 1961:113;

Matthysse and Denmark, 1981:342.

Amblyseius (Paraphytoseius) Ehara, 1967:77. 


\section{Paraphytoseius cracentis (Corpuz and Rimando)}

Ptenoseius cracentis Corpuz and Rimando, 1966:115. Paraphytoseius cracentis, Swirski and Golan, 1967:226.

SPECIMENS EXAMINED: Papua New Guinea: Near Wau, Edie Creek Road, elevation ca. $1700 \mathrm{~m}$, $6 \mathrm{FF}$, ex. Tephrosia sp.; elevation ca. $1400 \mathrm{~m}, 1 \mathrm{~F}$, ex. Piper sp.; W.E.I., 1 F, ex. Melinus minutiflora. Philippines: Mindanao, $1 \mathrm{~F}, 1 \mathrm{M}$, ex. Lantana sp., 30-VIII-80, E. Swirski.

PREVIOUS RECORDS: Philippines (Corpuz \& Rimando 1966, Swirski \& Golan 1967).

REMARKS: Our specimens closely resemble those of $P$. cracentis from the Philippines. These specimens have seta S5 present, macrosetae SgeIV and StiIV with distinctly swollen tips, St (basitarsus) IV only slightly enlarged at tip and St (distitarsus) IV narrowing toward tip, and all other setae on legs acuminate except for one dorsal seta on GeII. We consider them different from specimens from New Caledonia (McMurtry and Moraes 1984), which fit the original description of Swirski and Shechter (1961) of $P$. multidentatus, in which seta S5 is absent, all 4 macrosetae of leg IV are distinctly swollen at the tips, and most dorsal setae on $\mathrm{Ge}$ and Ti are rod-shaped or blunt-tipped (seta ad 2 of GeII is sharp-tipped). Although Matthysse and Denmark (1981) synonomized $P$. cracentis with $P$. multidentatus we consider them to be distinct species.

Average measurements of 2 female $P$. cracentis as follows: Dorsal shield length 268 , width $146, \mathrm{j} 133, \mathrm{j} 3$ 90, j4 4, j5 5, j6 6, J5 5, z2 10, z4 10, z5 4, Z1 9, Z4 71, Z5 95, s4 117, S5 14, r3 37, R1 23, SgeIV 22, StiIV 34, St (basitarsus) IV 38, St (distitarsus) 39.

We collected $P$. cracentis on the same plant (Tephrosia sp.) as Phytoseius hongkongensis. No potential food source was observed.

Species of Paraphytoseius share several presumably derived characters with many Phytoseius species, including: large "pores" on the dorsal shield near setae $\mathrm{z} 5$; thick, barbed setae $\mathrm{j} 3, \mathrm{~s} 4, \mathrm{Z} 4$ and $\mathrm{Z} 5 ; 3$ pairs of setae on the ventrianal shield in nearly longitudinal rows near lateral margins of shield; spatulate macrosetae on leg IV, setae $\mathrm{z} 4$ and s4 in close proximity, Z4 close and anterolateral to Z5; S2, S4 absent. Species of Paraphytoseius differ from those of Phytoseius in the following aspects: setae $\mathrm{z} 3$ and $\mathrm{s} 6$ absent, $\mathrm{Z} 1$ present; $\mathrm{r} 3$ on the membraneous cuticle rather than the dorsal shield; chelicerae multidentate.

Genus Amblyseius Berlese

Amblyseius Berlese, 1914:143.
Amblyseius multisetosus McMurtry \& Moraes, n.sp.

DIAGNOSIS: This species is unique among species in the genus Amblyseius by the presence of both setae $\mathrm{z} 6$ and $\mathrm{J} 3$.

FEMALE: (Figs. 5-7) (1 specimen measured). Dorsum: Dorsal shield reticulated, 336 long, 228 wide at widest level of proscutum. Setae j1 24, j3 13, j4 12, j5 12, j6 11, J2 12, J3 10, J5 8, z2 18, z4 14, z5 13, z6 13, Z1 13, Z4 12, Z5 34, s4 17, S2 16, S4 13, S5 12, r3 13, R1 13. All setae smooth. Peritreme: Extending forward to level of j1. Venter: Sternal shield with 3 pairs of setae. Posterior margin not discernable. Distances between ST1-ST3 50, ST2-ST2 61, G-G 65. Ventrianal shield vase-shaped, 102 long, 61 wide at level of ZV2 and 72 wide at level of anus. Chelicera: Movable digit 24 , apparently without teeth; fixed digit 23, apparently with 2 teeth. Spermatheca: With a very shallow bowlshaped cervix. Atrium elongate, sclerotized for a length of 8 microns. Legs: With blunt-tipped setae, in addition to setiform setae, on genu, tibia and tarsus of all legs and femur of leg I, but no characteristic macrosetae. Chaetotaxy of GeII 2, $\frac{2-2}{0}, 1$; GeIII 1, $\frac{2-2}{1}, 1$.

MALE: Unknown.

LOCALITY AND TYPE MATERIAL: Holotype female (in UCR) from Castanopsis sp., Edie Creek Road, near Wau, Papua New Guinea (elevation ca. 1600 m), VIII-6-79 (J.A. McMurtry).

REMARKS: Chileseius camposi Gonzalez \& Schuster also has what we interpret as setae $\mathrm{z6}$ and $\mathrm{J} 3$. However, it differs from $A$. multisetosus by having another seta which we interpret as Z3. Furthermore, setae J3, Z4, Z5 and S2-S5 are barbed in C. camposi and smooth in $A$. multisetosus, and the dorsal shield pattern is areolate in C. camposi and reticluate in $A$. multisetosus.

Amblyseius grandiductus McMurtry \& Moraes, n.sp.

DIAGNOSIS: This species resembles Amblyseius annae Schicha \& Gutierrez, A. newsami (Evans), $A$. neomarkwelli Schicha, $A$. anuwati Ehara \& Bhandhufalck, $A$. munsteriensis Van der Merwe and $A$. japonicus (Ehara) but differs from them by having a discshaped spermathecal cervix. A. nova differs from $A$. grandiductus by having funnel-shaped spermatheca and much longer SgeIV (86). It further differs from all those species except for $A$. neomarkwelli by having $\mathrm{r} 3$ and $\mathrm{R} 1$ on the dorsal shield.

FEMALE: (Figs. 8-11) (8 specimens measured). Dorsum: Dorsal shield 320 (307-336) long and 228 (221-235) wide at widest level of proscutum, with longitudinal striations laterally and some irregular strí- 


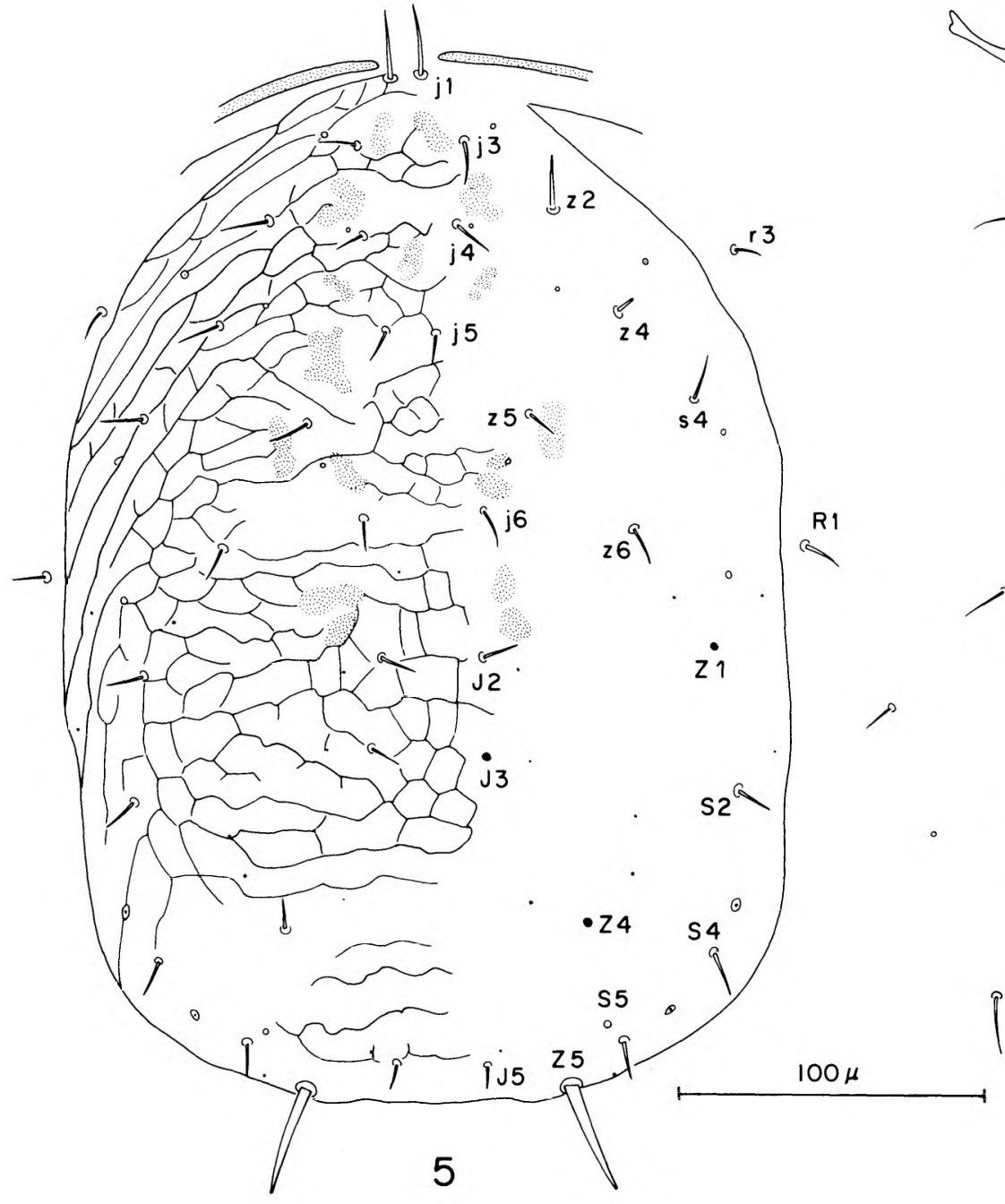

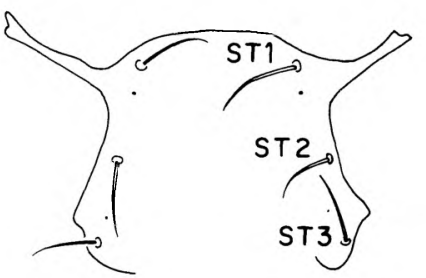
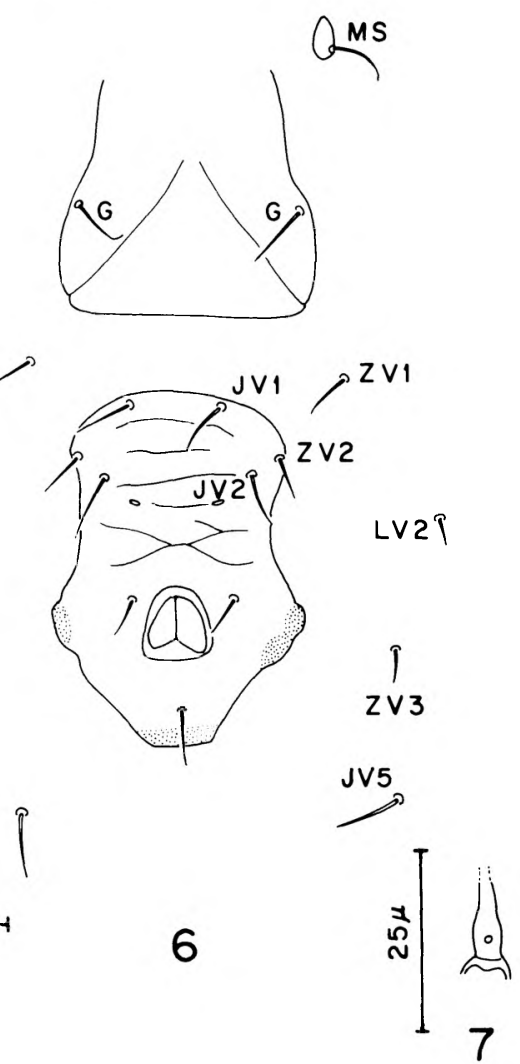

Figs. 5-7. Amblyseius multisetosus n. sp. Female: 5. dorsal shield

6. ventral surface 7. spermatheca

ations on posterior half of shield. Setae j1 12 (11-12), j3 13 (12-14), j4 8 (7-10), j5 8, j6 10 (8-11), J2 12 (11-13), J5 8 (7-8), z2 11 (10-13), z4 12 (11-13), z5 9 (8-11), Z1 12 (11-14), Z4 13 (12-17), Z5 74 (70-78), s4 14 (12-14), S2 12 (11-12), S4 12 (11-13), S5 7 (6-7), r3 11 (10-12), R1 9 (8-10). Z5 barbed; all other setae smooth. Setae r 3 and R1 on dorsal shield. Peritreme: Extending forward beyond level of $\mathrm{j} 1$. Venter: Posterior margin of sternal shield usually lobate. Distances between bases of setae ST1-ST3 47 (46-48), ST2-ST2 55 (54-56) and G-G 66 (62-68). Ventrianal shield with lateral margins concave posteriorly to JV2, 100 (96-104) long, 72 (67-76) wide at level of ZV2 and 72 (70-74) wide at level of anus. Chelicera: Movable digit 24, with 3 teeth; fixed digit 23, with 8 teeth. Spermatheca: Cervix disc-shaped; atrium distinct and globate. Major duct sausage-shaped, but not well visible in all specimens due to the positioning of the spermatheca. Legs: Macrosetae of the following lengths: SgeIII 23 (22-24), StiIII 17 (17-18), SgeIV 35 (32-38), StiIV 24 (23-25), StIV 34 (32-36); those of leg IV with a very small knob at tip. Chaetotaxy of GeII 2, $\frac{2-2}{0}, 1 ;$ GeIII $1, \frac{2-2}{1}, 1$.

MALE: Unknown.

LOCALITY AND TYPE MATERIAL: Holotype female (in USNM) and 7 paratype females (in UCR) from Casuarina oligodon, Wau, Papua New Guinea, 11-VI-79 (J.A. McMurtry).

Amblyseius papuaensis McMurtry \& Moraes, n.sp.

DIAGNOSIS: Amblyseius anuwati Ehara \& Bhandhufalck, $A$. japonicus (Ehara), A. hova Blommers and $A$. neomarkwelli Schicha differ from $A$. papuaensis in having striations on the dorsal shield and by the shape of the spermathecae. The first two 


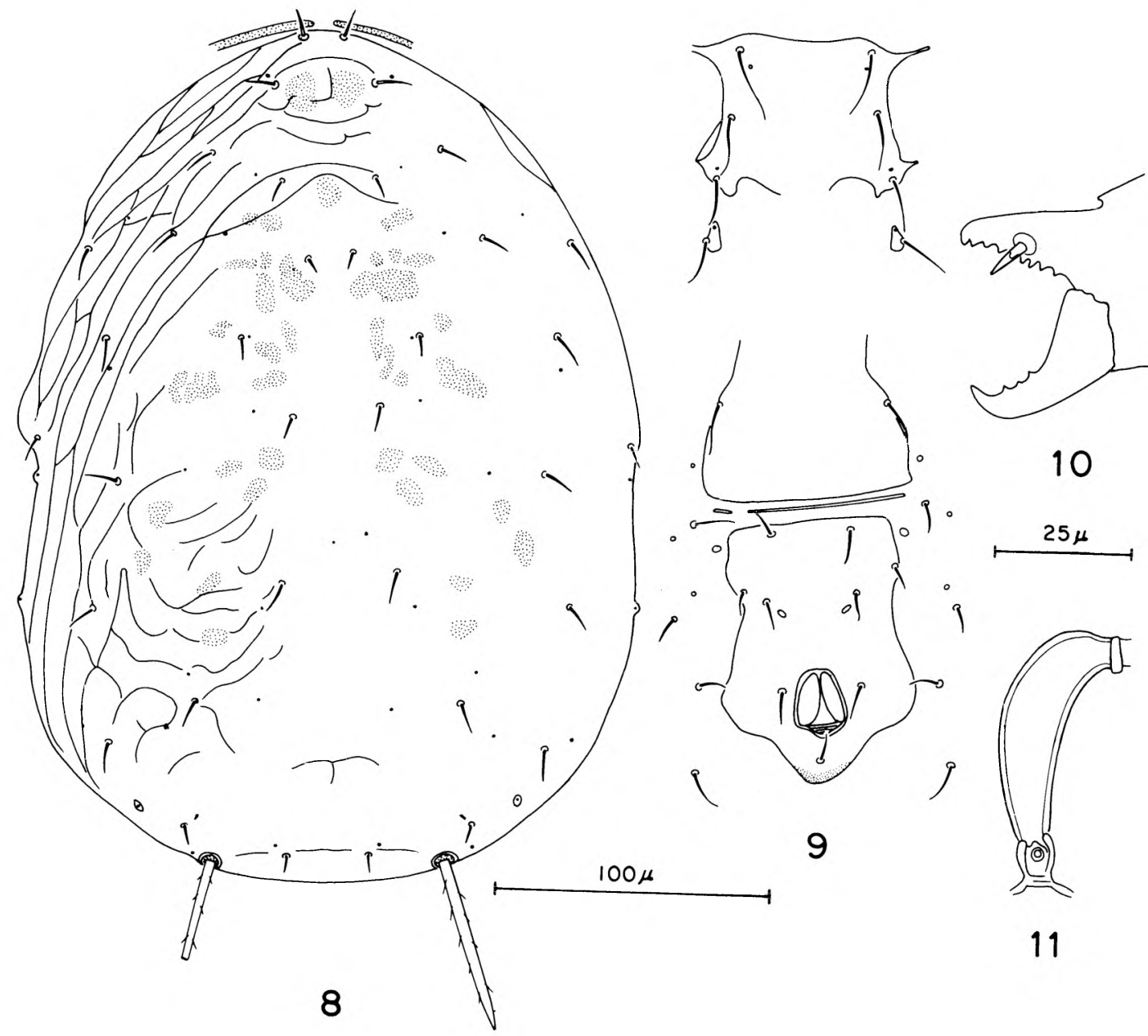

Figs. 8-11. Amblyseius grandiductus n. sp. Female: 8. dorsal shield 9. ventral surface 10. chelicera 11. spermatheca

species also differ by having shield-shaped ventrianal shields, and the other two species differ by having subrectangular ventrianal shields. $A$. newsami (Evans) can be distinguished from $A$. papuaensis by the shape of the spermatheca.

FEMALE: (Figs. 12-14) (2 specimens measured). Dorsum: Dorsal shield smooth, except for a few striae laterad to setae j3 and z2, 313 (305-322) long, 205 (202-209) wide at widest level of proscutum. Setae j1 16 (16-17), j3 11 (11-12), j4 7, j5 6, j6 7 (6-7), J2 12, J5 5 (5-6), z2 10 (10-11), z4 10, z5 9 (8-10), Z1 11 (11-12), Z4 17, Z5 62 (61-64), s4 13, S2 13 (12-13), S4 11 (11-12), S5 9 (8-10), r3 12, R1 12. Setae Z5 serrate; all the others smooth. Setae $\mathrm{r} 3$ and $\mathrm{R} 1$ on lateral membrane. Peritreme: Extending forward beyond level of j1. Venter: Posterior margin of sternal shield slightly concave. Distances between bases of setae ST1-ST3 54 (53-54), ST2-ST2 54 (53-54), G-G 59 (56-62). Ventrianal shield vase-shaped, 93 (90-96) long, 52 (52-53) wide at level of ZV2 and 63 (61-64) wide at level of anus. Setae JV2 near lateral margin of shield and only slightly mediad to setae ZV2. Chelicera: Movable digit 23, with 3 teeth; fixed digit 22, with 9 teeth. Spermatheca: Cervix funnel-shaped, 22 long; distinct atrium. Legs: Macrosetal lengths: SgeI 32, SgeII 30 (29-31), SgeIII 31, StiIII 24, SgeIV 46 (46-47), StiIV 33 (32-34), StIV 47 (46-48). All macrosetae setiform. Chaetotaxy of GeII 2, $\frac{2-2}{0}, 1 ;$ GeIII $1, \frac{2}{1}-\frac{2}{0}, 1$.

MALE: Unknown.

LOCALITY AND TYPE MATERIAL: Holotype female (in USNM) from Piper sp., Wau, Papua New Guinea, 27-V-79. Female paratype (in UCR) from Tectaria sp. (fern), Wau, Papua New Guinea, 2-VI-79 (J.A. McMurtry).

\section{Amblyseius newsami (Evans)}

Typhlodromus newsami Evans, 1953:450. 


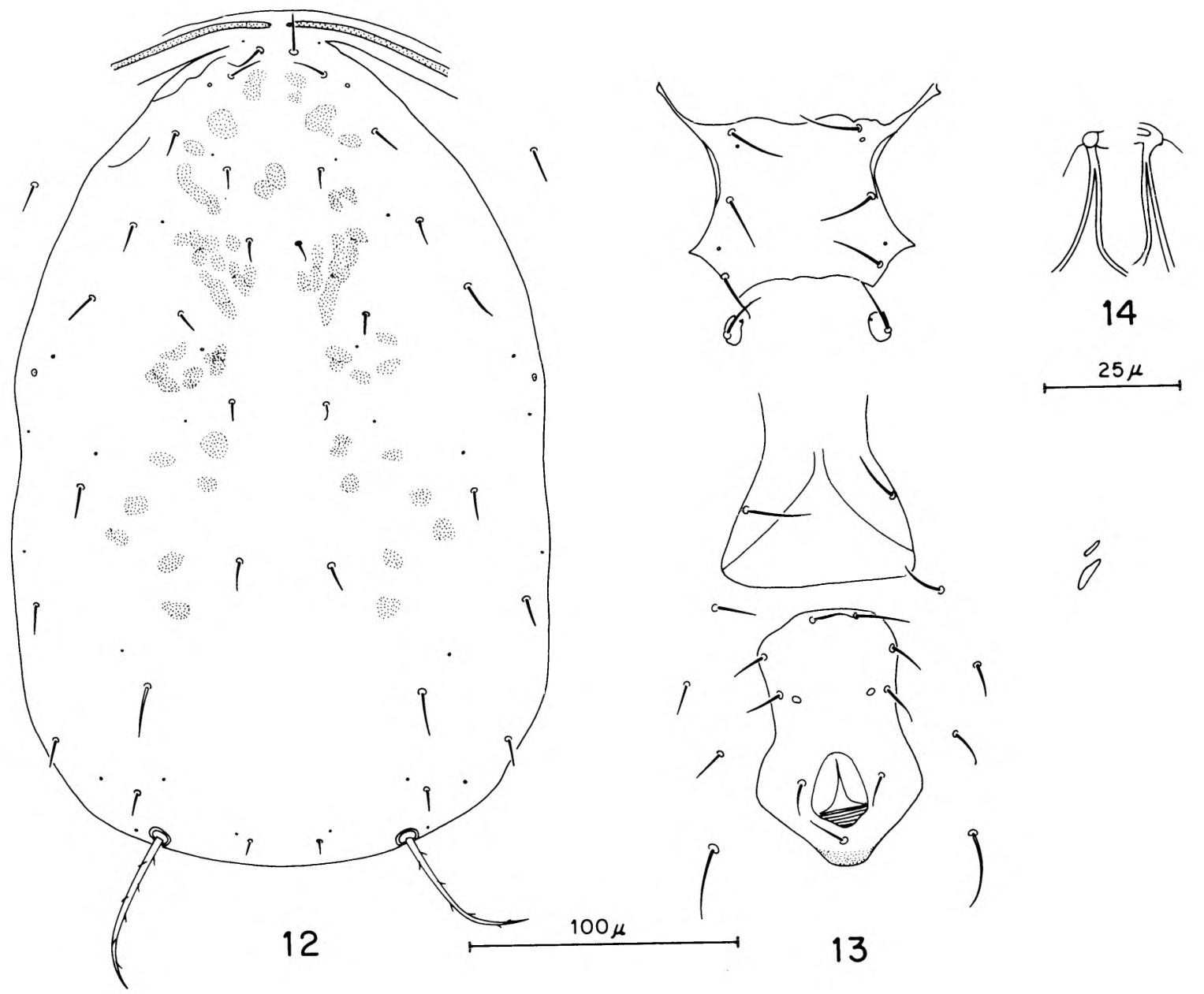

Figs. 12-14. Amblyseius papuaensis n. sp. Female: 12. dorsal shield 13. ventral surface 14. spermatheca

Typhlodromus (Amblyseius) newsami, Chant, 1959:153.

Amblyseius (Amblyseius) newsami, Ehara and Lee, 1971:61.

SPECIMEN EXAMINED: Holotype, from rubber plant (A. Newsam), Kuala-Lumpur-Malaya, in British Museum of Natural History.

PREVIOUS RECORDS: Malaysia (Evans 1953); Thailand (Ehara \& Bhandhufalck 1977); Hong Kong (Ehara \& Lee 1971, Swirski \& Shechter 1961); China Wu $(1981,1982)$ stated that this species also occurs in Taiwan and Japan.

DIAGNOSIS: This species closely resembles Amblyseius grandiductus McMurtry \& Moraes, n.sp., but is distinguished from it by not having a discshaped spermathecal cervix, by the longer $\mathrm{jl}$ (twice as long) and all leg macrosetae (about 50\% longer) and by having $\mathrm{r} 3$ and $\mathrm{R} 1$ on the lateral membrane.

FEMALE HOLOTYPE: (Figs. 15-18). Dorsum: Dorsal shield with a few lateral oblique striations, 348 long and 252 wide at widest level of proscutum. Setae j1 24, j3 10, j4 10, j5 10, j6 7, J2 8, J5 6, z2 8, z4 10, z5 10, Z1 13, Z4 17, Z5 58, s4 14, S2 13, S4 10, S5 8, r3 11, R1 8. All setae smooth, except for Z5 which are serrate. Setae $\mathrm{r} 3$ and R1 on lateral membrane. Peritreme: Extending forward beyond level of $\mathrm{j} 1$. Venter: Posterior margin of sternal shield indistinct. Distances between bases of setae ST1-ST3 55, ST2-ST2 72, G-G 68 . Ventrianal shield with lateral margins concave posteriorly to JV2, 108 long, 72 wide at level of anus. Chelicera: Movable digit 28, with 3 teeth; fixed digit 29, with 10 teeth. Spermatheca: Cervix of spermatheca sclerotized for only a short distance. Major duct connected to side of atrium. Legs: Macrosetal lengths: SgeI 20, SgeII 26, SgeIII 36, StiIII 26, SgeIV 55, StiIV 35 , StIV 44, all setiform.

\section{Amblyseius okinawanus Ehara}

Amblyseius (Amblyseius) okinawanus Ehara, 1967:72; Ehara and Lee, 1971:64; Ehara, 1972:156; Ehara 


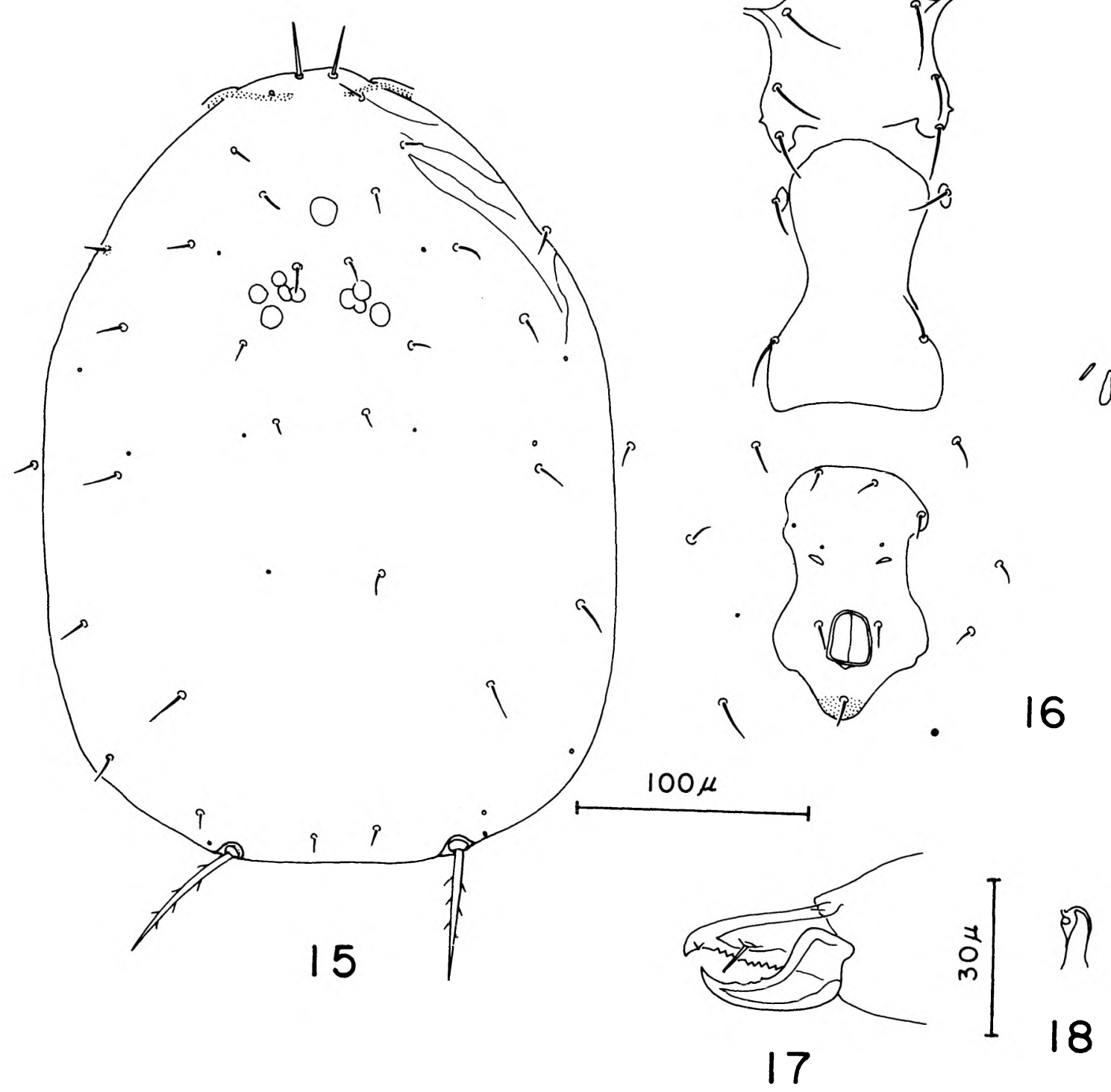

Figs. 15-18. Amblyseius newsami (Evans). Female: 15. dorsal shield 16. ventral surface 17. chelicera 18. spermatheca

and Bhandhufalck, 1977:58.

SPECIMENS EXAMINED: Okinawa: Tomiqusuku, 1 paratype female, ex. Verbena officinalis, 22-IV-66; Papua New Guinea: Near Wau: Edie Creek Road, elevation ca. $1400 \mathrm{~m}, 1 \mathrm{~F}$, ex. Cordyline terminalis; W.E.I. 5 FF, 1 M, ex. Melinus minutiflora.

PREVIOUS RECORDS: Japan (Ehara 1967, 1972, Ehara 1972, Ehara \& Hamaoka 1980); China (Wu 1981, 1982); Taiwan (Chang \& Tseng 1978, Lo 1970); Hong Kong (Ehara \& Lee 1971); Thailand (Ehara \& Bhandhufalck 1977); USSR (Wainstein 1975).
REMARKS: Our Papua New Guinea material resembled closely a paratype of $A$. okinawanus. Measurements (means and ranges) of 6 females as follows: dorsal shield length 333 (321-343), width 213 (206-222), j1 19 (18-19), j3 (12-13), j4 9 (7-10), j5 8 (6-10), j6 11 (11-12), J2 12 (11-12), J5 10, z2 12 (12-13), z4 12 (11-13), z5 9 (8-10), Z1 12 (12-13), Z4 31, Z5 78 (73-82), s4 17 (14-22), S2 16 (14-17), S4 15 (14-17), S5 15 (14-16), r3 13 (12-14), R1 9 (8-11), SgeII 10, SgeIII 17 (16-18), SgeIV 29 (28-30), StiIV 23 (22-28), StIV 51 (48-54), cervix of spermatheca 18 long. On at least one specimen, one of the setae R1 was on the dorsal shield rather than on the membrane adjacent to the shield. 


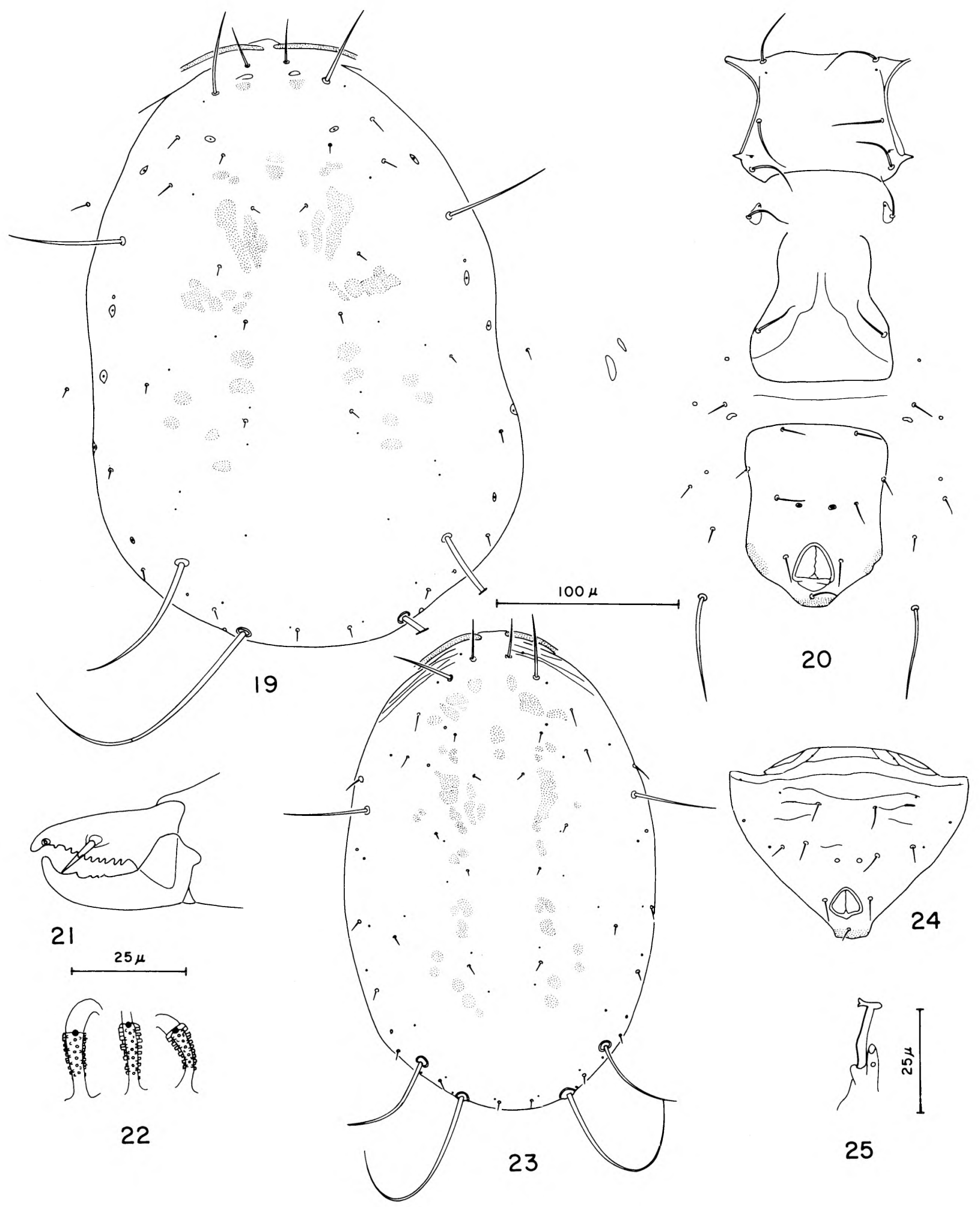

Figs. 19-25. Amblyseius asperocervix n. sp. Female: 19. dorsal shield 20. ventral surface 21. chelicera 22. spermatheca; Male: 23 . dorsal shield 24. ventrianal shield 25. spermatodactyl 
Amblyseius syzygii Gupta

Amblyseius syzygii Gupta, 1975:44; 1977:74. Amblyseius (Amblyseius) syzygii, Ehara and Bhandhufalck, 1977:56.

SPECIMENS EXAMINED: Papua New Guinea: Near Wau, Biawin village, $2 \mathrm{FF}$, ex. Carica papaya; W.E.I., 6 FF, 1 M, ex. Pinus sp.; 3 FF, 1 M, ex. Cordyline terminalis; $3 \mathrm{FF}, 1 \mathrm{M}$, ex. leaf of Musa sp. (banana).

PREVIOUS RECORDS: India (Gupta 1975, Gupta 1977, Gupta 1981, Gupta \& Nahar 1981); Thailand (Ehara \& Bhandhufalck 1977).

REMARKS: Our material conforms closely to the descriptions of Gupta (1975) and Ehara and Bhandhufalck (1977), and to the illustrations in the latter paper. Mean measurements from 5 specimens (range) as foliows: Dorsal shield length 344 (336-353), width 228 (221-238), j1 18 (17-19), j3 19 (19-20), j4 8 (7-8), j5 7, j6 9 (8-11), J2 12 (12-13), J5 8, z2 9 (8-10), z4 11 (10-12), z5 9 (8-10), Z1 13 (12-13), Z4 30 (26-31), Z5 74 (72-77), s4 16 (14-18), S2 12 (11-12), S4 11 (10-12), S5 9 (8-10), r3 14 (12-16), R1 11 (10-13), SgeI 24 (23-24), SgeII 26 (24-28), SgeIII 34 (31-36), StilII 30 (29-30), SgeIV 45 (43-50), StiIV 38 (36-40), StIV 54 (52-55).

Amblyseius asperocervix McMurtry \& Moraes, n.sp.

DIAGNOSIS: Amblyseius cinctus differs from this species in having a cervix with a smooth-textured wall. A. obtuserellus Wainstein \& Begljanov and Amblyseius obtusus (Koch) appear to have a similar rough-looking cervix wall, but both species have setae s4, Z4 and Z5 about 1.2, 1.3-1.8 and 1.6-2.0 times longer, respectively, than $A$. asperocervix. The spermathecae of both species are more cylindrical and the length of the cervix of $A$. obtuserellus is about twice that of $A$. asperocervix.

FEMALE: (Figs. 19-22) (10 specimens measured). Dorsum: Dorsal shield smooth, 334 (300-393) long, 237 (230-248) wide at widest level of proscutum. Setae j1 28 (24-31), j3 47 (43-50), j4 4 (4-5), j5 4, j6 4 (4-5), J2 5 (4-5), J5 7 (6-8), z2 10 (10-12), z4 7 (6-8), z5 4 (4-5), Z1 6 (5-7), Z4 87 (80-95), Z5 156 (144-166), s4 65 (65-66), S2 7 (6-8), S4 7 (6-8), S5 6 (6-8), r3 13 (12-14), R1 7 (6-8). All setae smooth. Peritreme: Extending beyond level of $\mathrm{j} 1$. Venter: Sternal shield with posterior margin straight. Distance between ST1-ST3 60 (58-64), ST2-ST2 71 (71-73), G-G 74 (70-78). Lateral margin of ventrianal shield slightly concave behind ZV2, 108 (96-115) long, 81 (77-84) wide at level of ZV2, 78 (74-80) wide at level of anus. Chelicera: Movable digit 37 (36-37) long, with 4 teeth directed backwards; fixed digit 32 (31-32) long, with 11 teeth. Spermatheca: Cervix ca. 14 long, slightly narrower near vesicle, with a rough appearance due to a number of external peg-like structures on the wall. Atrium not distinct. Legs: Macrosetae setiform, of the following lengths: SgeI 30 (29-32), SgeII 31 (30-34), SgeIII 38 (34-43), StiIII 27 (24-31), SgeIV 79 (70-84), StiIV 55 (47-64), StIV 63 (58-66). No erect seta on tarsus I. Chaetotaxy of GeII 2, $\frac{2-2}{0}, 1$; GeIII $1, \frac{2-2}{10}, 1$.

MALE: (Figs. 23-25) (5 specimens measured). Dorsum: Dorsal shield smooth, 252 (242-260) long, $170(162-178)$ wide at widest level of proscutum. Setae j1 21 (18-24), j3 37 (36-37), j4 5 (4-5), j5 4 (4-5), j6 4, J2 5 (4-5), J5 5 (5-6), z2 8, z4 7 (6-8), z5 4 (4-5), Z1 6 (5-7), Z4 58 (56-60), Z5 114 (106-120), s4 50 (48-52), S2 7 (6-8), S4 5 (4-6), S5 4 (4-5), r3 10 (10-11), R1 6. All setae smooth. Peritreme: Extending forward to level of j1. Venter: Ventrianal shield with a few transverse striae on the anterior half, 103 (96-106) long, 137 (133-144) wide at widest level, with 5 pairs of small and a pair of large preanal pores. Spermatodactyl: Shaft 16 (14-17) long. Legs: macrosetae setiform of the following lengths: SgeI 23 (22-24), SgeII 23 (20-24), SgeIII 25 (24-26), StiIII 21 (19-23), SgeIV 49 (46-54), StiIV 33 (30-37), StIV 50 (47-53).

LOCALITY AND TYPE MATERIAL: Holotype, 2 paratype females and 1 paratype male (USNM), 18 female and 4 male paratypes, and 5 nymphs (UCR) from Araucaria sp., Mount Susu Reserve, near Bululo, Papua New Guinea, 1-VI-79 (J.A. McMurtry).

\section{Amblyseius paucisetosus McMurtry \& Moraes, n.sp.}

DIAGNOSIS: This species differs from Amblyseius waltersi Schicha by its much smaller size (about $25 \%$ ) and by lacking seta $\mathrm{Z1}$. As in $A$. paucisetosus, $A$. parasundi Blommers, $A$. solus Denmark \& Matthysse and $A$. sundi Pritchard \& Baker, do not have seta Z1. However, those three species differ from $A$. paucisetosus by having tubular spermathecae. $A$. paucisetosus further differs from other Amblyseius species by lacking the 2 intermediate pairs of posteroventral setae (LV2 and ZV3).

FEMALE: (Figs. 26-28) (1 specimen measured). Dorsum: Dorsal shield smooth, 307 long, 196 wide at widest level of proscutum. Setae j1 20, j3 32, j4 5, j5 4, j6 7, J2 8, J5 6, z2 8, z4 7, z5 4, Z1 absent, Z4 53, Z5 138, s4 53, S2 8, S4 8, S5 8, r3 10, R1 7. All setae smooth. Setae r3 and R1 on lateral membrane. Peritreme: Extending forward to level of $\mathrm{j} 1$. Venter: Posterior margin of sternal shield straight. Distances between setae ST1-ST3 49, ST2-ST2 52, G-G 49. Ventrianal shield with lateral margins concave, 92 long, 66 


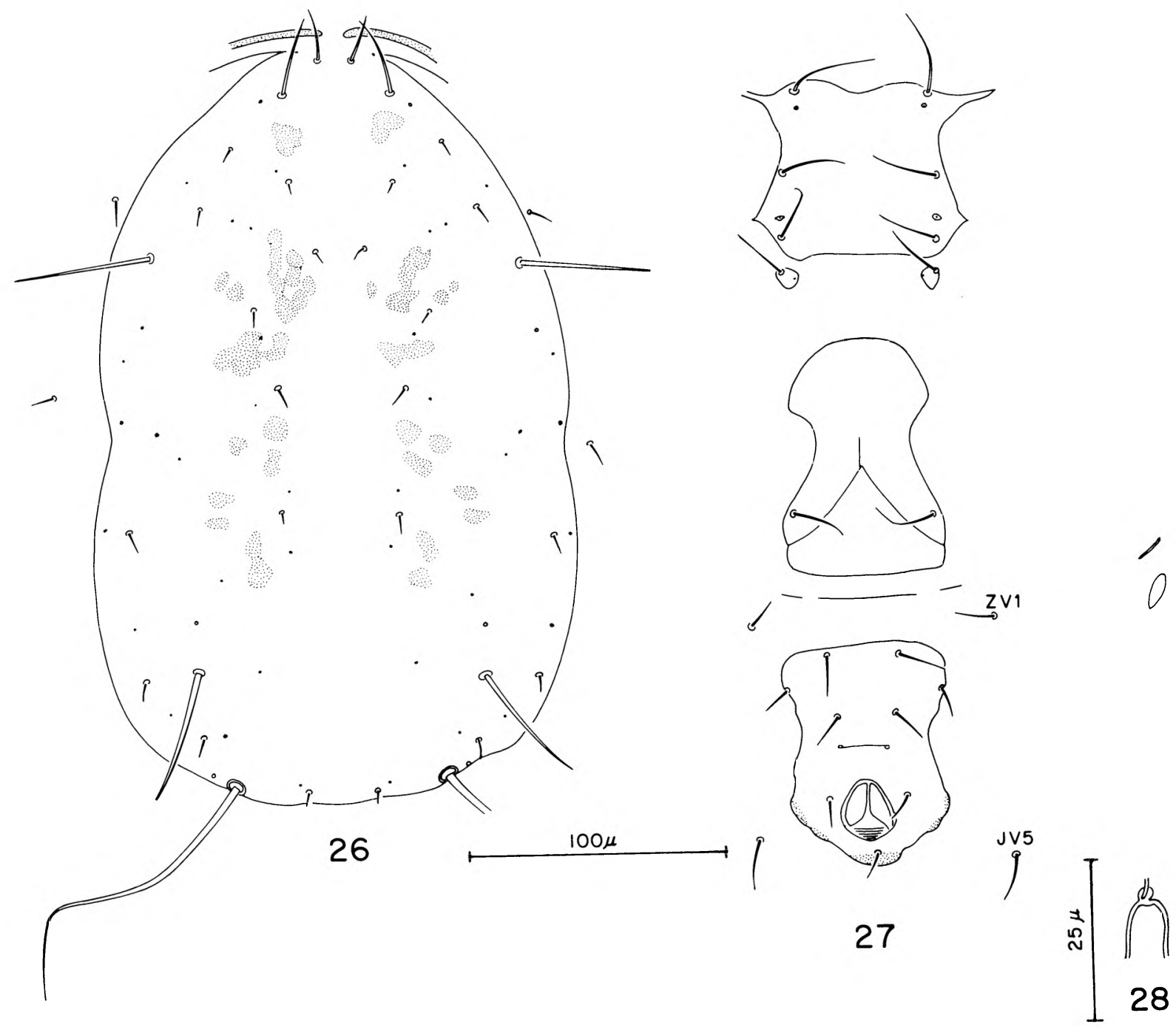

Figs. 26-28. Amblyseius paucisetosus n. sp. Female: 26. dorsal shield 27 . ventral surface 28. spermatheca

wide at level of ZV2, 64 wide at level of anus. Only 2 pairs of setae (ZV1 and JV5) surrounding ventrianal shield. Chelicera: Movable digit 35, with 12 or more teeth; fixed digit 31, apparently with 3 teeth. Spermatheca: Cervix cup-shaped, 8 long. Atrium globate. Legs: Macrosetal lengths: SgeI 35, SgeII 30, SgeIII 24, StilII 24, SgeIV 54, StiIV 48, StIV 54, all setiform. Chaetotaxy of GeII 2, $\frac{2-2}{0}, 1$; GeIII 1, $\frac{2-2}{10}, 1$. Erect seta present on tarsus I.

MALE: Unknown.

LOCALITY AND TYPE MATERIAL: Holotype female from Cryptocarya sp., Wau, Papua New Guinea, 26-V-79 (J.A. McMurtry), in UCR.
Amblyseius maai Tseng Amblyseius (Amblyseius) maai Tseng, 1976:123.

SPECIMENS EXAMINED: Taiwan: Dar Liau, 27-VIII-78, 2 FF, ex. Musa sp.; Papua New Guinea: near Wau, Biawin village, $2 \mathrm{FF}$, ex. Carica papaya; W.E.I., $1 \mathrm{~F}$, ex. Casuarina oligodon.

PREVIOUS RECORDS: Taiwan (Chang \& Tseng 1978, Tseng 1976).

REMARKS: Our Papua New Guinea specimens appeared indistinguishable from those from Taiwan. Setal measurements from 3 specimens of our material were nearly identical to those of 3 specimens from Taiwan. 
Amblyseius herbicolus (Chant)

Typhlodromus (Amblyseius) herbicolus Chant, 1959:84.

Amblyseius herbicolus, Daneshvar and Denmark, 1982:5.

Amblyseius largoensis, Muma, 1961:287 (in part).

Amblyseius deleoni Muma and Denmark, in Muma, et al., 1970:68; Shicha, 1981:107.

SPECIMENS EXAMINED: Papua New Guinea, Morobe Province: Numerous specimens from various localities and host plants: W.E.I., ex. Tectaria sp., Musa sp., Pandanus sp., unidentified Zingabaraceae, Casuarina oligodon, Eucalyptus torreliana, Piper sp., Araucaria sp., Coffea arabica, Lantana sp. Persea sp., Paspalum obiculare, Pinus sp.; Edie Creek Road: 1200 $\mathrm{m}$. ex. Ficus sp., $1400 \mathrm{~m}$. ex. Cordyline terminalis; $1600 \mathrm{~m}$ ex. Castanopsis sp., Elatostemma sp.; $1900 \mathrm{~m}$. ex. Piper sp.; near Wau, ex. Cryptocarya sp.; Bulolo, ex. Araucaria sp.

PREVIOUS RECORDS: See McMurtry \& Moraes (1984).

REMARKS: McMurtry and Moraes (1984) presented the characters which separate this species from others in the largoensis group.

$A$. herbicolus was the dominant phytoseiid collected in the Wau area. Although it was common on herbaceous plants, it was also collected on large trees, and was the only phytoseiid collected in second-growth Araucaria forests in the Bulolo area. This phytoseiid was also recorded from other highland areas of Papua New Guinea (Schicha and Gutierrez, in press). $A$. largoensis, a closely related and common species in the Pacific area, did not occur in our collections although Schicha and Gutierrez recorded it from several localities in Papua New Guinea, mainly lowland areas. $A$. herbicolus apparently extends to higher latitudes than A. largoensis (McMurtry and Moraes, 1984). Records from Papua New Guinea suggest that it also extends to higher altitudes than $A$. largoensis.

Genus Euseius Wainstein

Amblyseius (Amblyseius) section Euseius Wainstein, 1962:15.

Amblyseius (Euseius), DeLeon, 1965:125.

Euseius, DeLeon, 1966:86; Muma et al., 1970:12; McMurtry, 1983:257.

Euseius ovalis (Evans)

Typhlodromus ovalis Evans, 1953:458.

Typhlodromus (Amblyseius) ovalis, Chant, 1959:68. Amblyseius (Typhlodromalus) ovalis, Muma, 1961. Euseius ovalis, Gupta, 1978:335.
SPECIMENS EXAMINED: Papua New Guinea: W.E.I., $4 \mathrm{FF}$, ex. Ricinus communis; $5 \mathrm{FF}, 2 \mathrm{MM}$, ex. Eucalyptus torreliana; $1 \mathrm{~F}$, ex. Manihot sp.; $1 \mathrm{~F}$, ex. Coffea arabica; $1 \mathrm{~F}$, ex. Tectaria sp.

PREVIOUS RECORDS: Malaysia (Evans 1953); Philippines (Corpus \& Rimando 1966, Swirski \& Golan 1967); Fiji, Cook Islands, New Guinea (Collyer 1980); Mauritius Island (Moutia 1958); New Zealand (Collyer 1964); Hong Kong (Ehara \& Lee 1971, Swirski \& Shechter 1961); Taiwan (Chang \& Tseng 1978, Ehara 1970, Lo 1970); China (Liang \& Ke 1983, Wu 1981, 1982); Japan (Ehara 1967); India (Gupta 1978); Hawaii (Chant 1959, Prasad 1968); Mexico (Chant 1959) (misidentification?).

REMARKS: Redescriptions of E. ovalis were made by Schicha (1977), based on the holotype, and by Ehara (1967), based on material from Okinawa. Mean setal lengths (and ranges) of Papua New Guinea material, based on 6 specimens: j1 31 (30-32), j3 9 (8-10), j4 and j5 6 (5-7), j6 7 (6-7), J2 9 (8-10), J5 6 (5-6), z2 and z4 8 (7-9), z5 6, Z1 7 (6-9), Z4 6, Z5 50 (42-55), s4 11 (10-12), S2 8 (6-10), S4 9 (8-10), S5 8 (7-9), r3 11 (10-12), SgeIV 33 (30-36), StiIV 30 (27-36), StIV 55 (55-58), SgeIII 25 (24-26), cervix of spermatheca 12 (11-12) long. These measurements are generally somewhat shorter than those given by Schicha (1977) and Ehara (1967). The spermatheca resembles the figures of Narayanan et al. (1960), Ehara (1967), and Tseng (1976). The spermatheca was not visible in the holotype (Schicha 1977).

Genus Iphiseius Berlese

Iphiseius Berlese, 1921:95.

\section{Iphiseius dinghuensis Wu \& Qian}

Iphiseius dinghuensis Wu and Qian, 1982:61.

SPECIMENS EXAMINED: Papua New Guinea: Wau, W.E.I. 25-V-79, 4 FF, ex. Coffea arabica; $1 \mathrm{~F}$, ex. Araucaria sp. 1982).

PREVIOUS RECORDS: China (Wu and Qian,

REMARKS: A Papua New Guinea specimen is illustrated in Figs. 29-33. Ranges in lengths of setae (4 specimens) are shown in comparison to the measurements in the original description (in parentheses): $\mathrm{j} 1$ 17-18 (14), j3 18 (20), j4 19-22 (25), j5 24 (28), j6 43-46 (38), J2 48-54 (50), J5 11-12 (19), z2 24-25 (31), z4 31-40 (43), z5 19-20 (20), Z1 48-53 (51), Z4 54-55 (55), Z5 42-46 (50), s4 35-37 (44), S2 38-42 (45), S4 29-31 (38), S5 22-23 (28), r3 16-19 (16), R1 14-18 (10).

I. dinghuensis is very similar to I. formosanus Ehara 1970, being distinguished from that species by having longer setae $\mathrm{z} 4, \mathrm{Z} 1, \mathrm{~S} 4, \mathrm{j} 4, \mathrm{j} 5$ and $\mathrm{J} 2$ (Wu and Qian, 1982). 


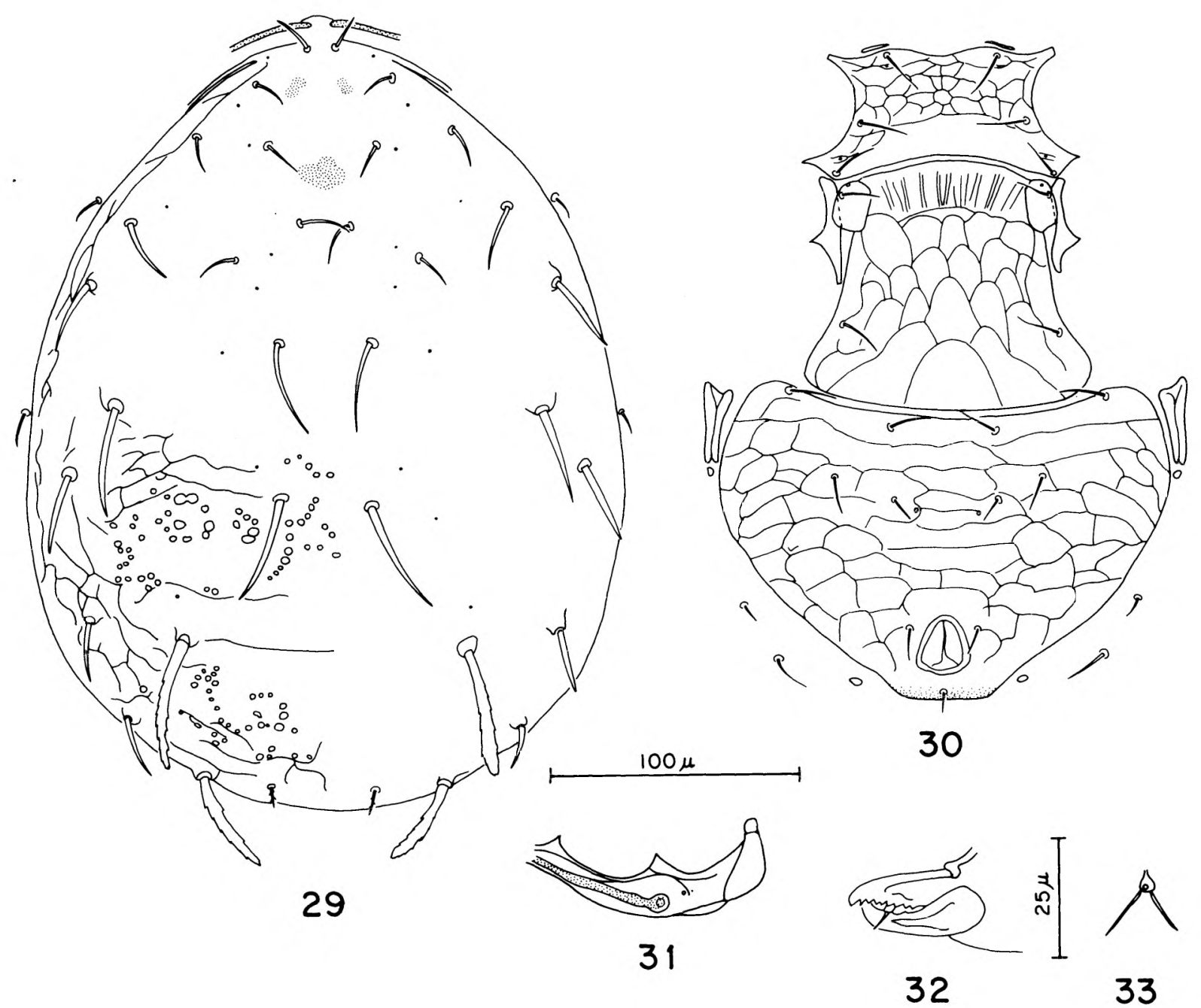

Figs. 29-33. Iphiseius dinghuensis Wu \& Qian. Female: 29. dorsal shield 30. ventral surface 31. peritrematal shield 32. chelicera 33. spermatheca

Pending further study and redefinition of Iphiseius and certain other genera in Amblyseiinae such as Paraamblyseius Muma and Iphiseiodes De Leon, we here retain $I$. dinghuensis in the genus under which it was described. The main diagnostic character used for the genus Iphiseius is the sclerotization of the lateral membrane from the dorsal shield ventrad to well below the bases of setae r3 and R1 (Chant, 1965). On this basis, the genus contains a heterogeneous assemblage of species, probably of several diverse lineages. Pronounced dissimilarity among species is evident in such features as shape and dentition of chelicerae, width and shape of ventrianal shield and dorsal shield chaetotaxy. For example, I. degenerans (Berlese), the type species, has some features in common with Euseius (see McMurtry, 1983) including the shape and dentition of chelicerae, the preanal setae being in a nearly transverse row, and distinctly wider genital shield than ventrianal shield (I. degenerans has the unusual condition of separate ventral and anal shields). I. dinghuensis, along with I. formosanus, I. mumai Prasad and I. gongylus Pritchard \& Baker, all have extremely wide ventrianal shields, but vary from one another in the number of $\mathrm{j}-\mathrm{J}$ setae and relative lengths of some setae on the dorsal shield. I. modestus Chant and Baker and I. robustus Chant and Baker have relatively narrow ventrianal shields and wider genital shields, and dorsal shield chaetotaxy typical of Amblyseius. There are 13 other species which were originally described in the genus Iphiseius. Chant et al. (1978) considered Iphiseius as a part of Amblyseius. 


\section{ACKNOWLEDGMENTS}

Appreciation is expressed to Mary McMurtry for assistance in collecting; to S. Ehara, Tottori University, Japan, D. MacFarlane, British Museum (Natural History) and Y. Tseng, Ministry of Economic Affairs, Tainan, Taiwan, for loan of specimens; and to the staff of the Wau Ecology Institute, especially the late J.L. Gressitt, W. Gagne, and A. Allison for cooperation and assistance in many ways.

\section{REFERENCES}

Berlese, A. (1914). Acari nuovi. Manipulus IX. Redia, 10:113-150.

Berlese, A. (1921). Acari, Myriapoda et Pseudoscorpiones hucusque in Italia reperta. I. Indice sinonimico dei generi e delle specie illustrate nei fascicoli lalol. Redia, 14:77-105.

Blommers, L. (1976). Some Phytoseiidae (Acarina: Mesostigmata) from Madagascar, with descriptions of eight new species and notes on their biology. Bijdragen tot Dierkunde 46(1):80-106.

Chang, Horng-Yih and Yi-Hsiung Tseng. (1978). A field survey of phytoseiid mites of tropical orchards in southern Taiwan. Plant Prot. Bull. 20:338-346.

Chant, D.A. (1959). Phytoseiid mites (Acarina: Phytoseiidae). Part I. Bionomics of seven species in southeastern England. Part II. A taxonomic review of the family Phytoseiidae, with descriptions of thirty-eight new species. Can. Entomol. Suppl. 12:166 pp.

Chant, D.A. (1965). Generic concepts in the Phytoseiidae (Acarina: Mesostigmata). Can. Entomol. 97:351-374.

Chant, D.A. and R.I.C. Hansell. (1971). The genus Amblyseius (Acarina: Phytoseiidae) in Alaska and Canada. Can. J. Zool. 49:703-758.

Chant, D.A., R.I.C. Hansell, H.J. Rowell and E. Yoshida-Shaul. (1978). A study of the family Phytoseiidae (Acarina: Mesostigmata) using the methods of numerical taxonomy. Can. J. Zool. 56:1330-1347.

Collyer, E. (1964). The occurrence of some mites of the family Phytoseiidae in New Zealand, and description of seven new species. Acarologia 64:632-646.

Collyer, E. (1980). Phytoseiidae (Acari) from the

, Pacific islands: note. New Zealand Entomol. 7:138-139.

Corpuz, L.A. and L. Rimando. (1966). Some Philippine Amblyseiinae (Phytoseiidae: Acarina). Philipp. Agric. 50:114-136.
Daneshvar, H. and H.A. Denmark. (1982). Phytoseiids of Iran (Acarina: Phytoseiidae). Int. J. Acarol. 8:3-14.

DeLeon, D. (1965). Phytoseiid mites from Puerto Rico with descriptions of new species (Acarina: Mesostigmata). Fla. Entomol. 48(2):121-131.

DeLeon, D. (1966). Phytoseiidae of British Guyana with keys to species (Acarina: Mesostigmata). In: Studies on the Fauna of Suriname and Other Guyanas. 8:81-102.

Denmark, H.A. (1966). Revision of the genus Phytoseius Ribaga (Acarina: Phytoseiidae). Fla. Dept. Agr. Bull. No. 6:1-105.

Ehara, S. (1967). Phytoseiid mites from Okinawa Island (Acarina: Mesostigmata). Mushi 40(6): 67-82.

Ehara, S. (1970). Phytoseiid mites from Taiwan (Acarina: Mesostigmata). Mushi 43(6)55-63.

Ehara, S. (1972). Some phytoseiid mites from Japan, with descriptions of thirteen new species. Mushi 46(12):137-173.

Ehara, S. and A. Bhandhufalck. (1977). Phytoseiid mites of Thailand (Acarina: Mesostigmata). J. Facult. Educ. Tottori Univ., Nat. Sci., 27(2): 43-82.

Ehara, S. and K. Hamaoka. (1980). A new Typhlodromus from Japan with notes on four other species of phytoseiid mites. Acta Arachnol. 29(1): 3-8.

Ehara, S. and L.H.Y. Lee. (1971). Mites associated with plants in Hong Kong. J. Facul. Educ. Tottori Univ., Nat. Sci., 22(2):61-78.

Evans, G.O. (1953). On some mites of the genus Typhlodromus Scheuten, 1857, from S.E. Asia. Ann. Mag. Nat. Hist. 6:449-467.

Gressitt, J.L. and N. Nadkarni. (1978). Guide to Mt. Kaindi: Background to montane New Guinea ecology. Wau Ecology Institute, Handbook No. 5. $135 \mathrm{pp}$.

Gupta, S.K. (1975). Mites of the genus Amblyseius (Acarina: Phytoseiidae) from India with descriptions of eight new species. Intern. J. Acarol. $1: 26-45$.

Gupta, S.K. (1977). Phytoseiidae (Acarina: Mesostigmata) of Andaman Nicobar Islands with descriptions of eight new species. Oriental Ins. 11: 623-638.

Gupta, S.K. (1978). Some Phytoseiidae from south India with descriptions of five new species. Oriental Ins. 12:327-338.

Gupta, S.K. (1981). Phytoseiidae (Acari) of Kumaon and Ganhwal Himalaya. Indian J. Acarol. 6: 24-34.

Gupta, S.K. and S.C. Nahar. (1981). Plant mites 
(Acari) of agricultural importance in Bihar. Contributions to Acarology in India (Proc. I All India Symp. in Acarol., Apr. 23-25, 1979, Bangalore): 6-11.

Liang, Lai-rong and Li-sheng Ke. (1983). Notes on the finlandicus group of Amblyseius Berlese in China. Acta Zootaxonomica Sinica 8:162-172.

Lo, P.K.C. (1970). Phytoseiid mites from Taiwan (I) (Acari: Mesostigmata). Bull. Sun Yat-sen Cult. Found. 5:47-62.

Matthysse, J.G. and H.A. Denmark. (1981). Some phytoseiids of Nigeria (Acarina: Mesostigmata). Fla. Entomol. 64:340-357.

McMurtry, J.A. (1983). Phytoseiid mites from Guatemala, with descriptions of two new species and redefinitions of the genera Euseius, Typhloseiopsis and the Typhlodromus occidentalis species group (Acari: Mesostigmata). Internat. J. Entomol. 25:249-272.

McMurtry, J.A. and G.J. de Moraes. (1984). Some phytoseiid mites from the South Pacific, with descriptions of new species and a redefinition of the Amblyseius largoensis species group. Internat. J. Acarol. 10:27-37.

Moutia, L.A. (1958). Contribution to the study of some phytophagous Acarina and their predators in Mauritius. Bull. Entomol. Res. 49:59-75.

Muma, M.H. (1961). Subfamilies, genera and species of Phytoseiidae (Acarina: Mesostigmata). Fla. St. Mus. Bull. Biol. Sci. 5:267-302.

Muma, M.H., H.A. Denmark and D. DeLeon. (1970). Phytoseiidae of Florida. Arthropods of Florida and neighboring land areas. 6:150 pp.

Narayanan, E.S., R.B. Kaur and S. Ghai. (1960). Importance of some taxonomic characters in the family Phytoseiidae Berlese 1916, (predatory mites) with new records and descriptions of species. Proc. Nat. Inst. Sci. India 26b:384-394.

Prasad, V. (1968). Amblyseius mites from Hawaii. Ann. Entomol. Soc. Amer. 61:1514-1521.

Ribaga, C. (1902). Gamasidi planticola. Rivista di Patologia Vegetale, 10:175-178.

Rowell, H.J., D.A. Chant and R.I.C. Hansell. (1978). The determination of setal homologies and setal patterns on the dorsal shield in the family Phytoseiidae (Acarina: Mesostigmata). Can. Entomol. 110:859-876.

Scheuten, A. (1857). Einiges uber milben. Anch.
Naturgesch., 23:104-112.

Schicha, E. (1977). Amblyseius victoriensis and Amblyseius ovalis compared with a new congener from Australia (Acari: Phytoseiidae). J. Aust. Entomol. Soc. 16:123-134.

Schicha, E. (1981). Two new species of Amblyseius Berlese from Queensland and New Caledonia compared with $A$. largoensis (Muma) from the South Pacific and $A$. deleoni Muma and Denmark from New South Wales (Acari: Phytoseiidae). J. Aust. Entomol. Soc. 20:101-109.

Schicha, E. (1984). Contribution to the knowledge of the genus Phytoseius Ribaga in Australia, the South Pacific and Indian Ocean region, with four new species and records of known species (Acarina: Phytoseiidae). Internat. J. Acarol. 10: 117-128.

Schicha, E. and S. Gutierrez. (In press). Phytoseiidae of Papua New Guinea, with three new species and new records of Tetranychidae (Acari).

Swirski, E. and Y. Golan. (1967). On some phytoseiid mites (Acarina) from Luzon Island (Philippines). Israel J. Agric. Res. 17:225-227.

Swirski, E. and R. Shechter. (1961). Some phytoseiid mites (Acarina: Phytoseiidae) of Hong Kong, with a description of a new genus and seven new species. Israel J. Agric. 11:97-114.

Tseng, Yi-Hsiung. (1976). Systematics of the mite family Phytoseiidae from Taiwan, with a revised key to genera of the world (II). J. Agric. Assoc. China, New Series, 94:85-128.

Wainstein, B. (1962). Revision du genre Typhlodromus Scheuten 1857 et systematique de la famille des Phytoseiidae (Berlese, 1916) (Acarina: Parasitiformes). Acarologia 4:5-30.

Wainstein, B.A. (1975). Predatory mites of the family Phytoseiidae (Parasitiformes) of Yaroslavl Province. Entomol. Rev. 54(4):138-143.

Wu, Wei-nan. (1981). Descriptions of five new species of phytoseiid mites from Fujian (Acarina: Phytoseiidae). Wuyi Sci. J. 1:205-213.

Wu, Wei-nan. (1982). Notes on the genus Amblyseius Berlese with descriptions of two new species from citrus orchards in south China (Acarina: Phytoseiidae). Acta Entomol. Sinica 25:96-101.

Wu, Wei-nan, and Qian, Xing. (1982). Description of a new species of Iphiseius from South China. Acta Zootaxonomica Sinica 7:61-63. 